JKM (Jurnal Kebidanan Malahayati),Vol 7,No.2.April 2021,

ISSN (Print) 2476-8944 ISSN (Online) 2579-762X, Hal 240-246

\title{
METODE LUDO DAN TEBAK GAMBAR TERHADAP PENGETAHUAN REMAJA TENTANG HIVIAIDS
}

\author{
Flora Niu ${ }^{1 *}$, Sri Wahyuni2 ${ }^{2}$ Marlisa Prismadini ${ }^{3}$ \\ 1,2,3Poltekkes Kemenkes Jayapura \\ *Korespondensi email niuflora@yahoo.co.id
}

\section{ABSTRACT THE LUDO METHOD AND GUESS THE PICTURE ON ADOLESCENT KNOWLEDGE ABOUT HIVIAIDS}

Background : according to the health profil of jayapura district, there are 2.973 cases of HIVIAIDS as of december 2018 cumulatively, there are 2.973 cases of HIV and AIDS 1.576 cases, 346 deaths, 275 AIDS cases, the highest number of HIVIAIDS attacks at productive age (15-29 years) as many as 2.752 cases.

Purpose : to determine the comparison of the ludo methode and gues the picture to the knowledge of adolescents about HIVIAIDS in Nimbokrag Village

Methods : comparative research. This research was carried out in nimbokrang villagein july 2020. The population in this study were 136 adolescents in nimbokrang, a sample of 30 respondents, this sample was taken by random smpling. The instruments used were the image guessing game questionnaire and the lludo game. This questionnaire has been tested for validity and reliability, data analysis techniques with bivariate analysis.

Result : based on the research of the pre-test and post-test of both methods, the pre-test and post-trst result of the ludo method have a $p$ value of $0,000<0,05$, so there is a difference between the knowledge of pretest and post-test in the ludo methode, on the pre-test and post-test. The image guessing method result in the $p$ value is $0,000<0,05$, so there is a defference between the pre test and post testin the image guessing method. If seen from the result of the effectiveness teat, the $p$ value is $0,175>0,05$, so there is no difference between the ludo method and guess the piture, which means that they are equally effective in increasing adolescent knowledge about HIVIAIDS.

Conclusion : from the both methods are result of the two methods above, it can be concluded that both methods are qually effective in increasing adolescent knowledge about HIVIAIDS.

Suggestion adolescents increase their knowledge in seeking information about HIV / AIDS by following counseling conducted by health workers and from various media, both print and electronic media

Keywords : knowledge, adolescent, HIVIAIDS, Ludo, Guess the picture.

\section{ABSTRAK}

Latar belakang: Menurut Profil Kesehatan Kabupaten Jayapura, (2018) kasus HIVIAIDS sampai dengan Desember 2018 secara komulatif sebanyak 2973 kasus HIV 1397 dan AIDS 1576 kasus, meninggal 346, kasus AIDS yang meninggaal berjumlah 275 orang, angka tertinggi HIVIAIDS menyerang pada usia produktif (15-29 tahun) sebanyak 2751 kasus.

Tujuan : Untuk mengetahui perbandingan Metode Ludo dan Tebak Gambar terhadap pengetahuan remaja tentang HIVIAIDS di Kampung Nimbokrang

Metode : Penelitian komperatif. Penelitian ini dilakukan di Kampung Nimbokrang pada bulan juli 2020. Populasi dalam penelitian ini adalah remaja dinimbokrang yang berjumlah 136 orang, dan sampel 30 responden, pengambilan sampel ini dilakukan dengan Sample Random Sampling. Instrumen yang digunakan adalah kuisioner permmainan tebak gambar dan permainan ludo. Kuisioner ini telah di uji validitas dan reliabilitasnya, teknik analisis data dengan analisis bivariat.

Hasil : Berdasarkan hasil penelitian pre test dan post test kedua metode tersebut didapatkan hasil pre test dan post test metode ludo $p$ valuenya $0,000<0,05$ maka terdapat perbedaan antara pengetahuan pre test dan post test pada metode ludo, pada pre test dan post test metode tebak gambar didapatkan hasil nilai $p$ valuenya $0,000<0,05$ maka terdapat perbedaan antara pengetahuan pre test dan post test pada metode tebak gambar. Jika dilihat dari hasil uji efektiivitas didapatkan hasil nilai $p$ valuenya adalah $0,175>0,05$ maka, tidak terdapat perbedaan antara metode ludo dan tebak gambar, yang artinya sama-sama efektif digunakan dalam meningkatkan pengetahuan remaja tentang HIVIAIDS. 
Simpulan : dilihat dari hasil kedua metode diatas dapat disimpulkan jika kedua metode sama-sama efektif digunakan untuk meningkatkan pengetahuan remaja tentang HIVIAIDS.

Saran para remaja meningkatkan pengetahuan dalam mencari informasi tentang HIVIAIDS dengan mengikuti penyuluhan yang dilakukan oleh tenaga kesehatan dan dari berbagai media baik media cetak maupun media elektronik

Kata Kunci : Pengetahuan, remaja, HIVIAIDS, Ludo, Tebak Gambar.

\section{PENDAHULUAN}

(United Nations International Children's Emergency Fund (UNICEF ) menyatakan jumlah kematian HIVIAIDS di kalangan remaja di seluruh dunia meningkat hingga 50 persen antara tahun 2005 dan 2012 dan menunjukkan tren mengkhawatirkan. UNICEF menyebutkan sekitar 71.000 remaja berusia antara 10 dan 19 tahun meninggal dunia karena virus HIV pada tahun 2005. Jumlah itu meningkat menjadi 110.000 jiwa pada tahun 2012. (UNICEF, 2017).

Menurut data Kementerian Kesehatan Republik Indonesia (Kemenkes RI), jumlah secara kumulatif sejak tahun 2005 sampai 2015, terdapat kasus HIV sebanyak 184.929 kasus yang didapat dari laporan layanan konseling dan tes HIV. Sementara, kasus AIDS sampai tahun 2015 sudah mencapai sejumlah 68.917 kasus. Kemudian kalangan remaja berusia 15-24 tahun merupakan kelompok yang rentan terinfeksi Human Immunodeficiency Virus (HIV), data Kemenkes RI secara kumulatif hingga 2015 menunjukkan, remaja yang terinfeksi HIV berjumlah 28.060 orang $(15,2 \%)$. Sebanyak 2.089 orang $(3 \%) \mathrm{di}$ antaranya sudah dengan AIDS. Pada tahun 2017 jumlah kasus yang didapat di Indonesia meningkat sebanyak 48.300 orang telah terinfeksi HIV.

Menurut Profil Kesehatan Kabupaten Jayapura, (2018) kasus HIVIAIDS sampai dengan Desember 2018 secara komulatif sebanyak 2973 kasus HIV 1397 dan AIDS 1576 kasus, meninggal 346 sehingga diperoleh angka kematian sebesar $11,6 \%$, kasus AIDS yang meninggaal berjumlah 275 orang atau sebanyak $17 \%$, HIV menyerang semua golongan umur, angka tertinggi HIVIAIDS menyerang pada usia produktif (15-29 tahun) sebanyak 2751 kasus $(92,53 \%)$ beitu juga dilihat dari pekerjaan HIVIAIDS menyerang pada ibu rumah tangga sebanyak 773 kasus $(26 \%)$ ini sangat berbahaya karena menyebar sampai populasi umum. Tahun 2018 masyarakat melakukan tes HIV sebanyak 77.002 orang dan hasilnya 219 orang positif HIV, dan 49 ibu hamil positif mengidap HIV.

Setelah dilakukan survey pendahuluan jumlah remaja yang ada di Kampung Nimbokrang sebanyak 136 orang. Dan telah dilakukan pendekatan dengan metode ceramah terhadap 10 orang remaja, 5 dari 10 orang masih berpengatahuan kurang tentang HIVIAIDS. Di Kampung Nimbokrang sendiri sudah pernah diberikan penyuluhan dengan metode ceramah namun hanya dilakukan 2 kali, setelah itu belum ada lagi penyuluhan yang dilakukan, maka belum berhasil meningkatkan pengetahuan tentang HIVIAIDS pada remaja di Kampung Nimbokrang.

Berdasarkan Latar Belakang tersebut maka penulis tertarik untuk melakukan penelitian dengan judul "Perbandingan metode Ludo dan Tebak Gambar terhadap pengetahuan remaja tentang HIVIAIDS di Kampung Nimbokrang".

Pengetahuan adalah hasil dari tahu dan ini terjadi setelah orang melakukan pengindraan terhadap suatu obyek tertentu. Pengindraan terjadi melalui pancaindra manusia, yakni indra pengelihatan, pendengaran, penciuman, rasa, dan raba dengan sendiri. Sebagaian besar pengetahuan manusia diperoleh melalui mata dan telinga (Notoatmodjo, 2010).

HIV (Human Immunodeficiency Virus) adalah virus yang memperlemah kekebalan tubuh manusia. HIV menyerang tubuh manusia dengan cara membunuh atau merusak sel-sel yang berperan dalam kekebalan tubuh sehingga kemampuan tubuh untuk melawan infeksi dan kanker menurun drastis. AIDS (Acquired Immuno Deficiency Syndrome) adalah sekumpulan gejala dan infeksi sindrome yang timbul karena rusaknya sistem kekebalan tubuh.(Syaiful,2015) Selain itu AIDS juga dapat menimbulkan komplikasi penyakit lainnya, seperti penyakit paru-paru, saluran pencernaan, saraf dan kejiwaan, tumor ganas (malignan) dan infeksi oportunistik lainnya (Sunaryati, 2011). AIDS disebabkan oleh HIV, virus yang dapat ditularkan dari orang ke orang cairan seksual, darah dan ASI. Di seluruh dunia, mayoritas infeksi HIV adalahditularkan melalui seks antara pria dan wanita, dan hampir setengah dari semua orang dewasa hidup dengan HIV adalah wanita. Tetapi kelompok orang tertentu telah terpengaruh secara khusus dan ini termasuk pengguna narkoba suntikan, pekerja seks dan lakilaki yang berhubungan seks dengan laki-laki. Dalam benak banyak orang, HIV dan AIDS sangat erat kaitannya dengan kelompok ini, yaitu 
dapat menyebabkan stigma dan prasangka yang lebih besar terhadap orang-orang yang telah diperlakukan seperti itu.(Akol 2014).Ada perbedaan pengetahuan pencegahan HIV pada remaja laki laki dan perempuan.(Sofri,2015)

HIV terutama berada dalam cairan tubuh manusia, seperti darah,cairan sperma, cairan vagina dan air susu. Zulkifli (2014). Penularan HIV Menjadi 2 cara yaitu Secara kontak seksual Melalui hubungan seksual dengan pengidap HIV tanpa perlindungan dan Secara non seksual

Permainan Ludo merupakan jenis permainan papan berpetak yang dimainkan oleh 2-4 orang pemain, dimana para pemain berlomba-lomba menjalankan pion mereka dari start sampai finish berdasarkan lemparan dadu (Jannah 2018).

\section{METODE}

Metode penelitian ini adalah Penelitian komparatif penelitian. Ditinjau dari tujuan penelitian yang akan dicapai, penelitian ini juga menggunakan pendekatan True (Arikunto,2010).Eksperimen. Sampel yang digunakan dalam penelitian ini adalah remaja yang ada di Kampung Nimbokrang sebanyak 30 orang. Dengan pembagian 15 orang untuk kelompok eksperimen dengan ludo, 15 orang untuk kelompok kontrol dengan metode tebak gambar. Dalam penelitian ini digunakan statistic uji paired t-test apabila data berdistribusi normal, dan data yang berdidtribusi tidak normal dapat menggunakan uji wilcoxon. Pada analisis ini, seluruh sampel diikut sertakan dengan menghitung jawaban yang dikosongkan sebagai jawaban salah. Dari uji normalitas data dengan menggunakan metode Shapiro-Wilk. Teknik pengumpulan data pada penelitian ini di ambil langsung dari remaja yang ada di nimbokrang.(Budiman,2013)

\section{HASIL PENELITIAN \\ Analisis Univariat}

Dari hasil penelitian menunjukan bahwa jumlah responden adalah 30 orang yang terbagi dalam 2 kelompok. Dari data yang diperoleh jumlah responden yang berjenis kelamin perempuan sebanyak 18 orang dan responden berjenis kelamin laki-laki sebanyak 12 orang. Pada masing masing kelompok berjumlah 15 orang dan telah dilakukan pre dan post tes menggunakan kuisioner dengan hasil sebagai berikut:
Tabel 1.

Pengetahuan sebelum diberikan metode Ludo

\begin{tabular}{lcc}
\hline \multicolumn{1}{c}{ Sebelum } & N & $\%$ \\
\hline Pengetahuan & & \\
Cukup & 11 & 73.3 \\
Baik & 4 & 26.7 \\
\hline
\end{tabular}

Tabel diatas menunjukan bahwa remaja yang memiliki pengetahuan cukup sebanyak 11 orang $(73.3 \%)$ dan 4 remaja lainnya berpengetahuan baik $(26,7 \%)$

Tabel 2.

Pengetahuan setelah diberikan Metode Ludo

\begin{tabular}{lcc}
\hline \multicolumn{1}{c}{ Sesudah } & N & $\%$ \\
\hline Pengetahuan & & \\
Baik & 15 & $100 \%$ \\
Cukup & - & - \\
\hline
\end{tabular}

Berdasarkan tabel di atas menunjukkan seluruh remaja memiliki pengetahuan yang baik tentang HIVIAIDS yaitu sebanyak 15 orang (100\%).

Tabel 3.

Pengetahuan Sebelum diberikan metode Tebak Gambar

\begin{tabular}{lcc}
\hline \multicolumn{1}{c}{ Sebelum } & N & $\%$ \\
\hline Pengetahuan & & \\
Cukup & 11 & 73.3 \\
Baik & 4 & 26.7 \\
\hline
\end{tabular}

Berdasarkan tabel di atas enunjukkan bahwa remaja yang memiliki pengetahuan cukup sebanyak 11 orang $(73.3 \%)$ dan 4 orang memiliki pengetahuan baik $(26,7 \%)$.

Tabel 4.

Pengetahuan sesudah diberikan metode Tebak Gambar

\begin{tabular}{lcc}
\hline \multicolumn{1}{c}{ Sesudah } & N & $\%$ \\
\hline Pengetahuan & & \\
Baik & 15 & 100 \\
Cukup & - & - \\
\hline
\end{tabular}

Berdasarkan tabel di atas menunjukkan sebanyak 15 orang memiliki pengetahuan baik $(100 \%)$. Untuk rata-rata pengetahuan dari masingmasing pre test dan post test kedua kelompok ada pada tabel berikut : 
Tabel 4.

Nilai rata-rata Pre test dan Post test Kelompok Eksperimen dan Kelompok Kontrol

\begin{tabular}{lll}
\hline & \multicolumn{2}{c}{ Rata-rata nilai } \\
\cline { 2 - 3 } & Pre Test & Post Test \\
\hline Kelompok Eksperimen (Ludo) & 72.8 & 91.8 \\
Kelompok Kontrol (Tebak Gambar) & 73.6 & 90.4 \\
\hline
\end{tabular}

Analisis Bivariat Dilakukan uji normalitas data pada kelompok eksperimen ludo dengan hasil data berdistribusi normal karena nilai skewness dibagi standar eror hasilnya $<2$. Karena data berdistribusi normal maka memenuhi syarat untuk di uji paired T test. Seperti tabel diibawah ini.

Tabel 5.

Uji Bivariat Pre Test dan Post Test pada Kelompok Eksperimen Ludo

\begin{tabular}{lccccc}
\hline $\begin{array}{l}\text { Perbedaan pre test dan post test } \\
\text { kelompok eksperimen (Ludo) }\end{array}$ & Mean & SD & SE & $\begin{array}{c}\text { P. } \\
\text { Value }\end{array}$ & N \\
\hline Pre Test Ludo & 72.8000 & 6.54872 & 1.69087 & 0.000 & 15 \\
Post Test Ludo & 91.8000 & 7.74781 & 2.00048 & & 15 \\
\hline
\end{tabular}

Berdasarkan data diatas dapat disimpulkan bahwa terdapat kenaikan tingkat pengetahuan remaja tentang HIVIAIDS pada pre test dan post test. Untuk mengetahui tingkat perbedaan pre tes dan post test dilihat dari nilai $p$-valuenya, dan didapatkan hasil $p$-valuenya adalah 0,000 sehingga $<0,05$ maka terdapat perbedaan antara pre test dan post test pada kelompok eksperimen ludo.

Tabel 7.

Uji Bivariat Pre Test Dan Post Test Kelompok Kontrol Tebak Gambar

\begin{tabular}{lccccc}
\hline $\begin{array}{l}\text { Perbedaan pre test dan post test } \\
\text { kelompok kontrol (tebak gambar) }\end{array}$ & Mean & SD & SE & P. value & N \\
\hline Pre test tebak gambar & 73.6000 & 3.92428 & 1.01325 & \multirow{2}{*}{0.000} & \multirow{2}{*}{15} \\
Post test tebak gambar & 90.4000 & 6.05687 & 1.56388 & \\
\hline
\end{tabular}

Berdasarkan data diatas dapat disimpulkan bahwa terdapat kenaikan tingkat pengetahuan remaja tentang HIVIAIDS pada pre test dan post tes. Untuk mengetahui tingkat perbedaan pre tes dan post test dilihat dari nilai p-valuenya, da didapatkan hasil $p$-valuenya adalah 0,000 sehingga $<0,05$ maka terdapat perbedaan antara pre test dan post test pada kelompok kontrol tebak gambar.

Tabel 8.

Uji Efektifitas Kelompok Eksperimen Dan Kelompok Kontrol

\begin{tabular}{lccccc}
\hline \multicolumn{1}{c}{ Perbedaan Kelompok } & Mean & SD & SE & P. Value & N \\
\hline Eksperimen (Ludo) & 19.0000 & 4.40779 & 1.13809 & \multirow{2}{*}{0.175} & \multirow{2}{*}{30} \\
Kontrol (Tebak Gambar) & 16.8000 & 4.24601 & 1.09631 & & \\
\hline
\end{tabular}

Berdasarkan data diatas dapat disimpulkan bahwa terdapat kenaikan tingkat pengetahuan pre test dan post tes pada kedua kelompok, jika diuraikan pada kelompok eksperimen memiliki nilai mean yang lebih tinggi yaitu 19 dan pada kelompok kontrol memiliki nilai mean 16,8 , dan setelah dilakukan uji independen simpel $\mathrm{T}$ test, pada kenaikan nilai pre test dan post test pada kelompok eksperimen Ludo dan kelompok kontrol Tebak gambar didapatkan hasil $P$ valuenya adalah 0,175 karena > 0,05 maka tidak terdapat perbedaan antara kelompok Ludo dan Tebak Gambar, yang artinya sama-sama efektif untuk meningkatkan pengetahuan remaja tentang HIVIAIDS.

\section{PEMBAHASAN}

Hasil Uji Bivariat Pre Test Dan Post Test Kelompok Eksperimen Ludo 
Berdasarkan hasil uji bivariat pada kelompok ekseperimen ludo, pada pre test didapatkan hasil yaitu 72.8000 dan post testnya didapatkan hasil 91.8000 dilihat dari hasil pre test dan post test pada kalompok eksperimen ludo maka terdapat kenaikan sebanyak 19.000. Untuk mengetahui apakah terdapat perbedaan pada pre test dan postnya maka dilihat dari nilai $p$ valuenya yaitu 0.000 sehingga < 0.05 maka dapat disimpilkan bahwa terdapat perbedaan antara pre test dan post test pada kelompok eksperimen ludo. . Hasil penelitian ini menunjukkan bahwa secara teoritis penggunaan permainan tradisional mampu mengembangkan keterampilan fisiknya, dan eksplorasi lingkungannya dengan tanpa bantuan orang lain.(Hakiki,2020)

\section{Hasil Uji Bivariat Pre Test Dan Post Test Kelompok Kontrol Tebak Gambar}

Berdasarkan hasil uji bivariat pada kelompok kontrol tebak gambar, pada pre test didapatkan hasil yaitu 73.6000 dan post testnya didapatkan hasil 90.4000 , jika dilihat dari hasil pre test dan post test kelompok kontrol tebak gambar maka terdapat kenaikan sebanyak 16.8000 . Untuk mengetahui apakah terdapat perbedaan antara pre test dan post testnya maka dilihat dari nilai $p$ valuenya yaitu 0.000 sehingga $<0.05$ maka terdapat perbedaan antara pre test dan post test pada kelompo kontrol tebak gambar. Sesuai dengan tahap perkembangan remaja, pada penelitian ini semua responden masuk pada kelompok fase remaja lanjut. Pada usia tersebut remaja mengalami perubahan biologis sehingga mengakibatkan perubahan penampilan pada remaja, dan perkembangan mental sehingga remaja memiliki kemampuan untuk menghipotesis dan berhadapan dengan abstraksi.(Senja 2020)

Keefektifan metode ludo dan metode tebak gambar Berdasarkan hasil dari uji keefektifan kedua metode tersebut dapat dilihat dari nilai mean kenaikan pre test kedua kelompok tersebut yaitu pada kelompok eksperimen didapatkan hasil meannya sebanyak 19.0000 dan pada kelompok kontrol tebak gambar didapatkan nilai meannya sebanyak 16.8000. untuk mengetahui mana yang lebih efektif dari kedua kelompok tersebut dapat dilihat dari nilai $p$ valuenya yaitu 0.175 sehingga > 0.05 maka dapat disimpulkan bahwa tidak terdapat perbedaan antara kelompok ludo dan kelompok tebak gambar yang artinya kedua kelompok tersebut sama-sama kuat atau sama-sama efektif digunakan untuk meningkatkan pengetahuan remaja tetang HIVIAIDS.

Berdasarkan hasil penelitian yang di terapkan pada teknik pembelajaran menggunakan metode Ludo yang telah dilakukan sebelumnya oleh
Merlyana Dwi Hapsari (2015) dibahas hasil penelitian yang dilakukan pada siswa siswi SMK guna meningkatkan penguasaan kosa kata bahasa jepang di SMK Mitra Karya Mandiri Ketanggungan Brebes. Dari hasil penelitian tersebut, hasil analisis data menunjukan nilai rata-rata dari persentase angket, hasilnya adalah $89,4 \%$ (tinggi), dari hasil tersebut dapat disimpulkan bahwa metode Ludo King secara efektif dapat meningkatkan jumlah kosakata bahasa jepang pada siswa-siswi SMK Mitra Karya Mandiri Ketanggungan Brebes. (Yusuf,2017)

Berdasarkan hasil penelitian yang diterapkan pada teknik pembelajaran menggunakan Metode Tebak gambar yang telah dilakukan sebelumnya oleh Pratiwi Oktaviana (2015) berdasarkan hasil tanggapan 30 siswa kelas bahasa pada aspek materi, aspek pembelajaran dan aspek media dan pengoperasiannya diperoleh hasil $87,1 \%$ yang termasuk dalam kategori "Sangat Baik" untuk digunakan sebagai media pembelajaran bahasa Prancis. penderita HIVIAIDS dengan koinfeksi TB Paru di RSUP Dr. Wahidin Sudirohusodo Makassar periode Januari - Juni 2016 didapatkan sebanyak 70 orang. Diketahui bahwa secara keseluruhan kelompok usia 30-40 tahun mencatat angka tertinggi yaitu $47,1 \%$, laki-laki mencatat angkat tertinggi yaitu $74,3 \%$, sebagian besar lebih banyak bekerja sebesar $74,3 \%$, sebagian besar mendapatkan hasil kadar hemoglobin $<10 \mathrm{~g} / \mathrm{dl}$ sebesar $51,4 \%$, lebih banyak pasien dengan hitung CD4 $<100 \mathrm{sel} / \mathrm{mm} 3$ yaitu $71,4 \%$, sebagian besar mendapatkan hitung limfosit total $<1000 \mathrm{sel} / \mathrm{mm} 3$ sebesar $67,1 \%$, seluruh pasien mendapatkan hitung LED $<100 \mathrm{~mm} / \mathrm{jam}$ sebesar $100 \%$, status gizi kurang berdasarkan IMT mencatat angka tertinggi yaitu $47,1 \%$, sebagian besar mendapatkan hasil pewarnaan BTA negatif, sebesar $64,3 \%$, dan lesi luas pada radiologi foto thoraks.mencatat angka tertingi yaitu $58,6 \%$.

Menurut Kamila 2017 Hasil Penelitian menunjukkan faktor yang berpengaruh pada perilaku pencegahan infeksi HIVIAIDS adalah pengalaman dan keterpaparan informasi terkait HIVIAIDS. Peningkatan penyuluhan pada remaja khususnya remaja laki-laki melalui peer grup yang melibatkan pihak sekolah menjadi hal penting untuk diprioritaskan mengingat usia remaja merupakan aset bangsa yang paling berharga. (Berek,2018)

Dari hasil penelitian sebelumnya dapat disimpulkan jika penelitian ini sejalan dengan penelitian sebelumnya, yang artinya sama-sama efektif digunakan untuk metode pembelajaran 
dalam meningkatkan pengetahuan remaja atau siswa-siswi baik $d$ sekolah atau di organisasi.

Menurut Priana,2018 Penelitian ini menemukan bahwa ada hubungan tingkat pengetahuan tentang HIVIAIDS dengan sikap pencegahan HIVIAIDS pada remaja. Remaja yang memiliki pengetahuan tentang HIVIAIDS yang lebih tinggi cenderung lebih baik dalam menentukan sikap terhadap pencegahan HIVIAIDS.

Menurut peneliti kedua metode tersebut sangat efektif digunakan dalam metode pembelajaran karena mudah dipahami dan materi yang disampaikan juga mudah diterima para remaja, pada kedua metode tersebut terdapat sesi tanya jawab dan diskusi antar tim, sehingga dapat menarik minat belajar untuk para remaja karena metode ini memiliki model permainan, sehingga remaja tidak cepat bosan dalam menerima materi yang disampaikan oleh peneliti. (Janah,2018)

\section{SIMPULAN}

Dilihat dari peningkatan pengetahuan remaja setelah di berikan metode ludo dan tebak gambar hasil dari uji efektivitas kelompok eksperimen Ludo dan kelompok kontrol Tebak Gambar didapatkan nilai $p$ valuenya adalah 0,175 , karena nilai $p$ valuenya $>0,05$ maka dapat disimpulkan tidak terdapat perbedaan antara metode ludo dan tebak gambar, yang artinya kedua metode tersebut samasama efektif digunaan untuk teknik pembelajaran dalam meningkatkan pengetahuan remaja tentang HIVIAIDS. Berdasarkan hasil dari data tersebut maka terdapat peningkatan pengetahuan remaja tentang HIVIAIDS setelah diberikan metode pembelajaran menggunkan permainan Ludo dan Tebak gambar. Yang artinya terdapat pengaruh antara metode ludo dan tebak gambar terhadap tingkat pengetahuan remaja tentang HIVIAIDS di nimbokrang.

\section{SARAN}

Diharapkan para remaja meningkatkan pengetahuan dalam mencari informasi tentang HIVIAIDS dengan mengikuti penyuluhan yang dilakukan oleh tenaga kesehatan dan dari berbagai media baik media cetak maupun media elektronik sehingga para remaja memiliki wawasan yang luas tentang HIVIAIDS agar para remaja terhindar dari resiko tertularnya virus HIVIAIDS. Bagi peneliti selanjutnya Diharapkan peneliti selanjutnya mengembangkan variabel dan instrumen penelitian sehingga diperoleh hasil penelitian yang lebih bervariasi.

\section{DAFTAR PUSTAKA}

Akol, J. M. (2014). Sero-prevalence and Factors Associated with HIV and HBV Infection in Patients Attending Juba Teaching Hospital, Southern Sudan (Doctoral dissertation).Ali, M. (2011). Psikoligo Remaja : Perkembangan Peserta Didik. Jakarta: Bumi Askara.

Arikunto. (2010). Proses Prosedur Penelitian : Suatu Pendekatan Praktek. Jakarta: Rineka Cipta.

Berek, P. A., Be, M. F., Rua, Y. M., \& Anugrahini, C. (2019). Hubungan Jenis Kelamin Dan Umur Dengan Tingkat Pengetahuan Remaja Tentang Hiv/Aids Di Sman 3 Atambua Nusa Tenggara Timur 2018. Jurnal Sahabat Keperawatan, 1(01), 4-13.

Budiman , A. (2013). Pengetahuan dan Sikap Dalam Penelitian Kesehatan. Jakarta: PT. Salemba Medika pp:4-7.

Hakiki, N., \& Khotimah, K. (2020). Penggunaan Permainan Edukatif Tradisional dalam Mengembangkan Motorik Kasar Anak Usia Dini. PRESCHOOL: Jurnal Pendidikan Anak Usia Dini, 1(1), 22-31.

Hapsari, M. D. (2015). Efektivitas Ludo Word Game (LWG) Dalam Meningkatkan Penguasaan

Jannah, M. M., \& Wiyatmo, Y. (2018). Jurnal Pengembangan Media Pembelajaran Permainan Ludo . Yogyakarta: Universitar Negeri Yogyakarta.

Kamila, A., Suratmi, T., \& Winidyaningsih, C. (2017). Analisis Perilaku GAY dalam Upaya Pencegahan Infeksi HIVIAIDS di Kabupaten Bandung Barat Tahun 2016. Jurnal Bidang IImu Kesehatan, 7(1), 4.

Kementrian Kesehatan Republik Indonesia. (2016). Situasi HIV/AIDS Di Indonesia. retrieved from:

www.depkes.go.id/article/view/17010600004/ situasi-hiv-aids-di-indonesia-html.

Ngudi, E, Muryani, L, Nuraini, N, \& Ritianawati, N. (2010). Hubungan Tingkat Pengetahuan Tentang HIVIAIDS pada Mahasiswa Reguler Universitas Indonesia dengan Sikapnya Terhadap. Universitas Indonesia, Depok.

Nurhasanah Nur Azmi M, A. (2017). Jelajah Sejarah Melalui Ludo Carpet : Upaya Mewujudkan Generasi Nasional Bagi Annak Sekolah Dasar . Lampung: Penelitian Pendidikan Insani.

Priastana, I. K. A., \& Sugiarto, H. (2018). Hubungan Tingkat Pengetahuan tentang HIVIAIDS dengan Sikap Pencegahan HIVIAIDS pada 
Remaja. Indonesian Journal of Health Research, 1(1), 1-5.

Sari, D. M., Tanjung Anitasari, I. K., \& Werdani, K. E. (2018). Hubungan Pengetahuan dan Sikap Tentang HIVIAIDS dengan Stigma Masyarakat terhadap ODHA di Kecamatan Banjarsari Kota Surakarta (Doctoral dissertation, Universitas Muhammadiyah Surakarta).

Sofni, L. M., \& Dewi, Y. I. (2015). Perbandingan pengetahuan dan sikap antara remaja putra dan remaja putri tentang tindakan pencegahan HIVIAIDS (Doctoral dissertation, Riau University).

Sugiyono. (2016). Statistika Penelitian. Bandung Alfabeta.

Sunaryati, S. (2011). 14 Penyakit Paling Sering Menyerang dan Sangat Mematikan . Yogyakarta: FlashBooks.
Sudikno,et al.2010.Jurnal Pengetahuan HIVIAIDS Pada Remaja Di Indonesia

Syaiful, B. (2015). Strategi Belajar Mengajar. Jakarta: Rineka Cipta.

UNICEF. (2017). HIV and AIDS. www.unicef.org/hiv.

Widiastutik , d. (2009). Kesehatan Reproduksi. Jakarta: Fitramaya.

Widoyono. (2014). Penyakit Tropis Epidemiologis, Penularan, Pencegahan, dan Pemberantasannya. Jakarta: Erlangga.

Yusuf , N. F. (2017). Karakteristik Penderita HIVIAIDS Dengan Ko-Infeksi Tuberkulosis Paru di Rumah Sakit Umum Pusat Wahidin Sudirohusodo. Makassar: Universitas Hassanudin Fakultas Kedokteran Makassar.

Zulkifli. (2014). Menejemen Sistem Informasi. Jakarta : PT. Gramedia Pustaka Utama. 